\title{
Text-to-Speech-Based Textbook for University Students with Visual Impairments in English Syntax Inclusive Learning:
}

\author{
A Need Analysis Study \\ Sunardi \\ English Department, Faculty of Humanities \\ Dian Nuswantoro University \\ Indonesia \\ sunardi@dsn.dinus.ac.id \\ Raden Arief Nugroho \\ English Department, Faculty of Humanities \\ Dian Nuswantoro University \\ Indonesia \\ arief.nugroho@ dsn.dinus.ac.id
}

Purwanto

Master Program in Informatics Engineering

Dian Nuswantoro University

Indonesia

purwanto@dsn.dinus.ac.id

\begin{abstract}
This study aims at finding needs and expectations for designing a user-friendly textbook of English syntax which can be used by university students with visual impairment in inclusive learning. English syntax learning is chosen because of its certain difficulties undergone by visually-impaired students, particularly those dealing with syntactic analysis which is commonly visualized in a tree diagram notation. The subjects of this study were those involved in English syntax learning including visuallyimpaired students, lecturers, and Pertuni (Indonesian Blind Union). Three lecturers, six visually-impaired students, and three Pertuni staffs participated in the focus group. The study was conducted in Semarang City by including all the English departments which have students with visual impairments and offer English syntax course in their curricula as well as implement it in inclusive learning. The data were collected by observation, in-depth interview, and focus group discussion. The findings show that a user-friendly textbook of English syntax for visually-impaired students should accommodate the following main needs and expectations: (1) the textbook is presented in digital format to be easily accessed by a visually-impaired student using a screen reader, such as JAWS (Job Access with Speech), (2) the text book is supplemented with an add-ons program called English Syntactic Analyzer - that can guide a visuallyimpaired student in analyzing a syntactic unit, and (3) the textbook enables visually-impaired students to have the same access to learning activities and success as the normal students in the class.
\end{abstract}

Keywords-English syntax, inclusive education, text-to-speechbased textbook, syntactic analyzer, visually impaired student

\section{INTRODUCTION}

All this time persons with disabilities and impairments tend to be considered by common people as objects of protection, treatment, and aids rather than subjects for some rights [1], [2]. This perspective makes persons with disabilities isolated from common society and placed in exclusive places and facilities. People assume that persons with disabilities cannot cope with their life problems in common society [3]. Moreover, according to [4] \& [5], this thought creates the practices of segregation education which make persons with disabilities isolated from those without disabilities. In this segregation education, persons with disabilities study in their special schools and are not allowed to study in common schools.

In the education sector, this thought creates segregated education practices which separate disabled students from normal ones. Disabled students are placed in a special school which is widely known as School of Special Educational Needs (SLB) and they are prohibited to study in a regular school. As a result, the disabled students are alienated by public. Public tends to perceive disabled students' activities in the society as an oddity especially when they are not designed for the disabled ones. This practice will isolate disabled students from any activities in the society and grow their dependency to others. Therefore, this phenomenon creates discrimination towards disabled students [4], [5].

A model of inclusive education is hoped to overcome problems of segregated education faced by disabled students. This model provides opportunities for disabled students to study in the same education and learning environment with the 
normal ones. Thus, disabled students have wider chances to acquire a high standard of education which is suitable to their needs and capabilities and is not discriminative to all students [6], [7].

As opposed to normal or sighted students, blind students have a different education access. This happens because blind students cannot use their vision in their daily life [8], [9], thus they are placed in a school of special educational for the blinds which isolates them from public activities. When disabled students study in a regular school, they have to follow a learning process designed for nondisabled students. Because of their visual disability, disabled students cannot adjust the learning process to their needs and abilities which eventually results in a learning breakdown. This problem can be overcome through the practice of inclusive education by facilitating appropriate learning aids for them, modifying their learning environment, and using an alternative teaching technique which enables them to participate actively and effectively in the learning process.

In accordance with the advancement in technology, there are some computer-based technologies, like Speech Technology and Refreshable Braille Display, which allow disabled people to get access to information like sighted people normally do [1]. However, most of the software technologies use English as the medium of instruction. The interaction between computer (software) and user is done by using English. This can create a barrier for disabled people who do not have sufficient English knowledge. On the other hand, these technologies become the information gateways to the world. Furthermore, in the context of English learning materials, English is mostly used as the language of instruction. In the education context, a sufficient ability in operating Speech Technology can also help disabled people to study learning materials better.

Unlike primary and secondary education systems that are equipped with school of special educational for the blinds, tertiary education system is not equipped with any special school for the blinds. Disabled students who want to continue their tertiary education must study in a regular class together with sighted students. This fact proves that the model of inclusive education for tertiary level cannot be neglected by universities or study programs that welcome disabled students including visually impaired students. And also, these disabled students must have equal rights and chances to succeed in their study.

English syntax is the study of how words are combined to create grammatical units: phrases, clauses, and sentences. One of the ways to study the structure of a syntactic unit is by using a visually notational tree diagram that shows the formation of the unit hierarchically. However, such a visual tree diagram is helpful only for sighted persons. This creates serious problems for persons with visual impairment. In learning activity, such a problem in understanding sentence structure by visually-impaired students will result in a discriminated access of learning success for them. For a balanced access of learning for visually-impaired students in learning English syntax, a user-friendly textbook for visuallyimpaired students is strongly needed.
This study focuses on finding the needs and expectations for designing a user-friendly textbook of English syntax which can be used by university students with visual impairment in inclusive learning.

\section{METHOD}

The subjects of this study were those involved in English syntax learning including visually-impaired students, lecturers, and Pertuni (Indonesian Blind Union) staffs. Three lecturers, six visually-impaired students, and three Pertuni staffs participated in the study. The study was conducted in Semarang City by including three English departments which have students with visual impairments and offer English syntax course in their curricula as well as implement it in inclusive learning.

The data were collected by observation, in-depth interview, and focus group discussion to know the recent practices of English syntax teaching and learning attended by visually-impaired students. The process of data collection focused on the problems that may appear in the teaching and learning activities, particularly on the use of learning materials.

Observations were conducted to some inclusive classrooms where visually-impaired students learned English syntax together with other sighted students. In-depth interviews were conducted to the lecturers and visuallyimpaired students after completion of the classrooms, to know their learning expectations and problems about the classrooms. To get more comprehensive data and information on expected learning materials, focus group discussions consisting of lecturers, visually-impaired students, and Pertuni staffs were conducted.

\section{RESULTS AND DISCUSSION}

\section{A. Problems Faced by Visually Impaired Students}

Based on the observation to the classroom activities where visually impaired students study in the classroom of sighted students, and the in-depth interview with the visually impaired students, there are at least three pedagogical problems experienced by the visually impaired students. Those problems include little opportunity to learn cooperatively with their sighted classmates, difficulty in accessing the learning materials presented by the lecturers in printed textbooks, and difficulty in understanding the English syntactic analysis which was usually presented in a tree diagram on the white board.

Problem dealing with little opportunity to learn cooperatively with their sighted classmates derives from the learning method used by the lecturer. In explaining the learning materials to the students, the lecturers used more lecturing methods in which the lecturers positioned themselves the centre of attention in the learning activities. Such instructional method of course benefits more the sighted students but ignores the existence of some visually impaired students in the classroom. This is illustrated by the following quotes: 
I don't know how to differentiate the learning method for sighted students and visually impaired ones. I just do what I usually do in the classroom. Furthermore, I don't incorporate technology when I teach them. (Lecturer 1)

My or our biggest problem is when the lecturers think that we can do all sighted persons can do. Although I don't want to be treated differently, I still have limitations, though. (Visually Impaired Student 1)

Furthermore, with lecturing method, the visually impaired students have little access to the learning materials discussed in the classroom. This learning activity is not relevant to the learning principles of visually impaired students in learning activities, namely: concreteness, integrated experience, and learning by doing [3], [10], [11], [12]. This problem can be overcome, for example, by applying cooperative learning that gives more opportunities for visually impaired students to collaborate with other sighted students in discussing and doing the works given by the lecturers.

Students with visual impairment also have problems in accessing the learning materials provided by the lecturers. Most of the learning materials are presented in printed text books which are visually difficult to be accessed by the students with visual impairment. This problem happens because the lecturers do not consider the visual impairment faced by some students in the classroom. This is illustrated by the following quote:

We never used assistive technology or books that enable students with visual impairment access out teaching materials. (Lecturer 2 and 3)

To overcome this problem, the lecturers may convert the printed learning materials into digital files, such as doc or .pdf, that can be accessed by the visually impaired students by using screen reader program, for example JAWS for Windows.

The third problem faced by visually impaired students in learning activities, particularly those in English Syntax, deals with segmenting the constituents that form a syntactic unit (phrase or sentence) in the form of tree diagram. This is illustrated by the following quote:

We agree that the hardest subject is English Syntax. We never 100\% understand about the sentence segmentation, since it needs visualization (Visually Impaired Students 1, $2,3,4,5,6)$

In the English Syntax classrooms under study, the lecturers usually use tree diagram as a special notational device to make the structure of a phrase or sentence "visible". English Syntax Course studies how phrase and sentence are analyzed to know the relations of the constituents that make the phrase or the sentence. According to [13], [14], [15], the analysis of a sentence may be thought of as a procedure involving a number of discrete steps. The final result of the analysis is a treediagram (in this case, to be read from left to right) in which every constituent has received a function-category label, that is a label which indicates what function the constituent has in a larger whole as well as to what category it belongs.

\section{B. Overview from Special Needs School Lecturers and Expert in Inclusive Education}

Based on the in-depth interview with special needs school teachers and expert in inclusive education, there are at least two pedagogical objectives that need to be addressed to visually impaired students. The objectives incorporate building inclusive atmosphere in the classroom and integrating learning materials that are equipped with an assistive technology. Moreover, the special needs school teachers and expert agree that the latter objective is easier to apply than the former objective, since building institutional provision on inclusiveness can be realized if all organizational levels in the university understand the characteristics and importance of inclusive education.

One example of attitudinal barrier that often occurs in the classroom interaction is the awkward communication between sighted persons, i.e. lecturers and students, and students with visual impairment. The expert and special needs school teachers agree that handling visually impaired students is trivial. On one part, these students explicitly state that they want to be treated as individuals who are not disabled or impaired. Conversely, they also often underline that their visual impairment is a major part of their identity, thus assistance from their environment is inevitable. To overcome this issue, the expert and special needs school teachers suggest that detailed communication must be generated. Basic formulaic expressions, such as "if there's anything you need to do, don't hesitate to bother me" or "can I help you to....?" can be used when communicating with students with visual impairment.

When dealing with building inclusive atmosphere, institutional provision is a top priority. There are two continuums pertaining to generating institutional provision. One point refers to those who think that institutional support is not really necessary and the other point refers to those who have the opposite attitude. The former continuum is perceived as an attitude that underlines the importance of selfdetermination and independence. In contrast, the latter continuum presents the problems that stem from the educational barriers faced by visually impaired students, ranging from physical or navigational barriers to psychological barriers. Physical or navigational barriers include campus navigability that disallows disabled students to access independently, for example the lack of signage or assistive technology for students with visual impairment. Furthermore, psychological barriers are realized into negative feeling or attitude toward students with visual impairment. The special needs school teachers and expert agree that the solutions for these barriers take a lengthy process. As mentioned above, understanding the characteristics of students with visual impairment is not an easy task. It needs a sense that the success of applying inclusive education might enhance the quality of not only visually impaired students, but also the university itself. To conclude, the gap between these continuums needs to be balanced. Students with visual impairment must be given an errand that requires independent act. On the other extent, the necessity of using a peer assistant for them must also be designed as well. 


\section{Prototype of English Syntax Textbook Based on Text-to- Speech}

The last objective deals with the integration of learning materials with suitable access technology. Nowadays, this integration is a common case. Technology is seen as the entrance to the world knowledge. The expert and special needs school teachers have the same opinion that what needs to be developed today is text-to-speech-based textbook for students with visual impairment. This book allows visually impaired students to learn about the content independently. Pertaining to the learning on English Syntax subject, such notational visualization of sentence structure is more easily understood by sighted students but creates extreme difficulties for visually impaired students to understand. Students with visual impairment cannot access information presented in visual format. They rely on their audio senses to access information and "to see" the world. Based on this perspective, a tool that can facilitate students with visual impairment to understand English sentence analysis is much needed. The text-to-speechbased textbook should enable students with visual impairment to access the sentence and analyze it gradually from the higher level to the lowest level.

The prototype of the textbook modified for visuallyimpaired students in understanding English syntax learning materials, particularly the syntactic analysis, can be diagrammed in Fig. 1.

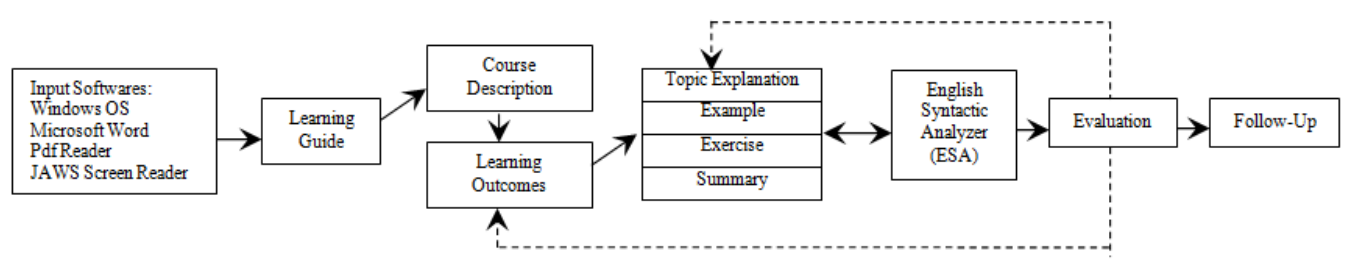

Fig. 1. Prototypical textbook based on text-to-speech

As Fig. 1 states, the modified textbook is designed to be a digital book which can be easily accessed by a low vision or even visually impaired student. This digital book requires some supporting softwares: Windows operating system, text reader programs such as Microsoft Word or Acrobat Reader, and a popular JAWS Screen Reader. In addition to these programs, the textbook is also supplemented with an adds-onprogram which can guide visually-impaired students to do syntactic analysis by understanding the forms and categories of the constituents that make a syntactic unit. The adds-onprogram is called English Syntactic Analyzer (ESA) as its function implies. For the ease of student's using the textbook, it provides the students with the learning guide which gives learning information and procedures to learn the course materials using the modified textbook. Each chapter of the textbook begins with short description of the course and expected learning outcomes to preview what to learn and what learning competencies in the chapter. The main part of the chapter is the discussion which consists of topic explanation, related examples and non examples of the topic, exercise, and summary of the topic. In this part, ESA adds-on-program is used to help visually impaired student understand and analyze the structure of a syntactic unit, such as phrase or sentence. The syntactic analyzer will enable students with visual impairment to access the phrase or sentence and analyze it gradually from the higher level to the lowest level. The steps of syntacic analysis begin by inputting the phrase or sentence to be analyzed in the available field. With JAWS Screen Reader, the program will read command to input a phrase or sentence to analyze after. After the phrase or sentence is typed, the user may proceed to analyze the sentence from the main level to the last level.
The analysis starts by segmenting the main level into constituents that together make up the sentence. The number of constituents that make up the sentence will determine the number of levels to be analyzed. For example, a sentence The clever students in this class will do the final tests next week is segmented into four constituents: constituent1 the clever students in this class, constituent 2 will do, constituent 3 the final tests, and constituent4 next week. Each constituent will be assigned function-category labels in its larger structure. In assigning function-category labels of a constituent, the user may choose the relevant function or category that corresponds to the constituent from a pull-down list. Whenever a particular level contains a constituent that is capable of further analysis, this analysis takes place on a lower level. The analysis of the main level of the above sentence can be presented in Fig. 2.

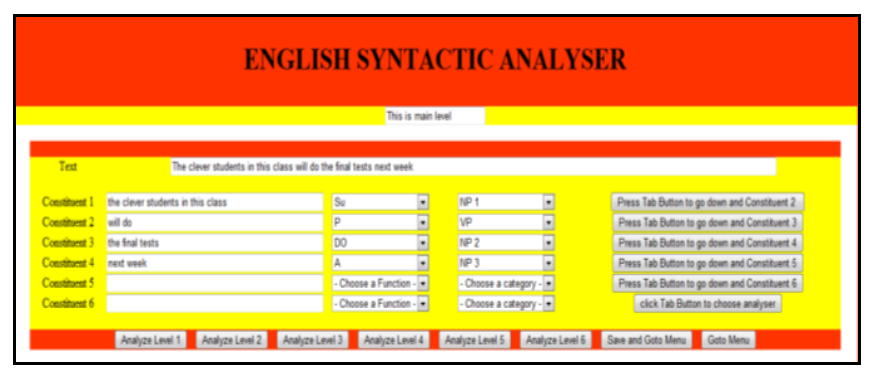

Fig. 2. The main level analysis in ESA

Upon understanding the learning materials and making syntactic analysis in each chapter, students will proceed to take evaluation on the topic learned. The result of the evaluation will give feedbacks on the accomplishment of the learning outcomes. The last part of each chapter is follow-up 
that directs student to explore more about the learning materials which are not already understood or proceed to learn the next chapter.

\section{CONCLUSION}

The findings show that a user- friendly textbook of English syntax for visually-impaired students should accommodate the following main needs and expectations: the textbook is presented in digital format to be easily accessed by a visuallyimpaired student using a screen reader, such as JAWS (Job Access with Speech); the textbook is supplemented with an add-ons program - called English Syntactic Analyzer - that can guide a visually-impaired student in analyzing a syntactic unit; and the textbook enables visually-impaired students to have the same access to learning activities and success as the sighted students in the class.

\section{ACKNOWLEDGMENT}

The authors express sincere thanks to the Directorate of Research and Community Services (DRPM), Ministry of Research and Higher Education. This article is the result of a research funded by the Directorate under Hibah Penelitian Sosial, Humaniora, dan Pendidikan (PSHP) research scheme 2017.

\section{REFERENCES}

[1] D. Tarsidi, "Komputer dan Ketunanetraan". 2007. Accessed on 12 February 2013 from http://dtarsidi.blogspot.com/2007/07/komputerdanketunanetraan.html.

[2] Joyti Khadka, et al. Listening to Voices of Children with Visual Impairment: A Focus Group Study. British Journal of Visual Impairment 30(3), 182-196, 2012.

[3] Kim de Verdier. Inclusion in and out of the Classroom: A Longitudinal Study of Students with Visual Impairment in Inclusive Education. Britsh Journal of Visual Impairment, 34 (2), 132 - 142, 2016.

[4] D. Tarsidi, "Dampak Ketunaan pada Pembelajar Bahasa". 2009. Accessed on 12 February 2013 from http://dtarsidi.blogspot.com/2009/03/dampak-ketunanetraan-terhadap.html.
[5] D. Tarsidi, "Disabilitas dan Pendidikan Inklusif pada Perguruan Tinggi". 2012. International Workshop on Inclusive Education. Malang: Universitas Brawijaya, November 10 - 11, 2012.

[6] Ministry of National Education (Depdiknas). "Peraturan Menteri Pendidikan Nasional Republik Indonesia Nomor 70 Tahun 2009 tentang Pendidikan Inklusif bagi Peserta Didik yang Memiliki Kelainan dan Memiliki Potensi Kecerdasan dan/atau Bakat Istimewa”. Jakarta: Depdiknas, 2009.

[7] Ministry of National Education (Depdiknas). "Permendikbud No. 46 Tahun 2014 tentang Pendidikan Khusus, Pendidikan Layanan Khusus dan atau Pembelajaran Layanan Khusus pada Perguruan Tinggi”. Jakarta: Depdiknas, 2014.

[8] Michael McLinden and Graeme Douglas. 'Accesss to Leaning and Learning to Sccess': Analysing Distinctive Role of Speacialist Teachers of Children and Young People with Vision Impairment in Facilitating Curriculum Access through an Ecological Theory, British Journal of Visual Impairment, 34(2), 179 - 197, 2016.

[9] John Ravenscroft. A Discussion on What is a Qualified Teacher of Pupils with Visual Impairment. Britsh Journal of Visual Impairment, 33 (3), $161-166,2015$.

[10] Direktorat Pembinaan Sekolah Luar Biasa. Pedoman Khusus Penyelenggaraan Pendidikan Inklusif: Kegiatan Pembelajaran. Jakarta: Direktorat Jenderal Manajemen Pendidikan Dasar dan Menengah, Depdiknas. 2006.

[11] Direktorat Pembinaan Sekolah Luar Biasa. Pedoman Khusus Penyelenggaraan Pendidikan Inklusif: Media Pembelajaran. Jakarta: Direktorat Jenderal Manajemen Pendidikan Dasar dan Menengah, Depdiknas. 2007.

[12] Direktorat Pembinaan Sekolah Luar Biasa. Pedoman Khusus Penyelenggaraan Pendidikan Inklusif: Model Modifikasi bahan Ajar Pendidikan Inklusi. Jakarta: Direktorat Jenderal Manajemen Pendidikan Dasar dan Menengah, Depdiknas. 2007.

[13] Flor Aarts and Jan Aarts. English Syntactic Structures: Functions and Categories in Sentence Analysis. Oxford: Pergamon Press. 1987.

[14] Andrew Carnie. Syntax: A Generative Introduction (Third Edition). Oxford: Wiley-Blackwell. 2012.

[15] M.A.K. Halliday and Christian M.I.M. Mathiessen. Halliday's Introduction to Functional Grammar (Fourth Edition). London: Routledge. 2014. 